U.S.S.R. have each organized many expeditions for the express purpose of making such collections, and just before the War the Executive Council of the Imperial Agricultural Bureaux expanded its scope by financing such an expedition to South and Central America for the collection of wild varieties of potatoes; a collection that may become of outstanding importance, as one of the surprising results of the War has been the way the potato has invaded countries, particularly in the Mediterranean, that barely knew it before, and if this crop is to remain in these countries it will be necessary to raise varieties suited to their conditions.

The development of machinery for ensuring that these collections, once made, are not dispersed is much more difficult, and the Hankey Committee recommends that the Executive Council should interest itself in this problem and be able to furnish the next British Commonwealth Scientific Conference with an accurate picture of the collections in existence. The problem might become urgent at any time, as certain institutions throughout the Empire have already made such collections, and if for any reason one of these institutions had to give up carrying on its collection, or even to reduce it, there is no organization to save the collection from dispersal or loss. These collections obviously are imperial assets, for they may contain wild species of little value at the present time but with characters of great importance for other centres or other times. That such collections are international assets as well, so that this is genuinely a problem for international co-operation, is no excuse for the Governments of the British Empire not setting up a co-operative organization to safeguard such eollections wherever they may be.

The creation and preservation of such large living collections of plant species has thus just begun to be a field of imperial co-operation, but, as already stressed, it must also become a field for international co-operation, if for no other reason than that it will be a very potent instrument for raising the standard of living in those countries suffering from chronic malnutrition. Such an organization is, therefore, almost an essential corollary to the 'freedom from want' clause in President Roosevelt's famous four freedoms, and to the relevant sections of the Atlantic Charter and the Hot Springs Conference.

\section{LIBRARY SERVICE IN GREAT BRITAIN}

$\mathrm{T}$ HE detailed report on "The Public Library System of Great Britain" prepared by Mr. L. R. McColvin for the Library Association, which was published in September 1942 (see Nature, March 20, 1943, p. 317), has now been considered by a special committee of the Library Association appointed by the Council of the Association for that purpose. This committee, after considering the report and comments thereon from branches and sections of the Library Association, public library committees and other interested groups and individuals, has presented its report to the Council; and an official statement of the Association's proposals for the re-organization and development of the public library service of Great Britain has now been issued*. The proposals can thus be fittingly considered against the plan for educational reform now before the nation, with the enhanced demands on the public library service which such reform is likely to stimulate. Equally important, the proposals throw some light on the broad question of local government efficiency and reform, on which opinion is not the less concerned on account of the Government's refusal to consider the matter during the War.

On the latter question, it is unnecessary to remark more than that while the Government may decline to consider local government reform as a whole, we are unlikely, without some definite action, to obtain the improvement in public library services and facilities which is not only desirable but also probably essential if the full advantage of the new educational proposals is to be reaped. Merely to remove the permissive stumbling block in the Acts of Parliament by which public libraries exist will not carry us far when the resources of many local authorities are so small, and an attempt to deal with the regional question alone might well prove an obstacle to subsequent more fundamental reform.

Without recapitulating the conclusions of $\mathrm{Mr}$. McColvin's report, it may be recalled that his survey gave an outstanding impression of generally unsatisfactory provision and of a badly organized service. Even the best administered and supported libraries in Great Britain are still unable to realize the reasonable ideals of their own committees and officers. The wide variations in standards of provision in different areas are depriving many men and women of educational and cultural opportunities which others enjoy. The service is often most defective where it would be most valuable. The permissive principle stands condemned; and many local authorities appear both incompetent as well as inadequately provided with resources so far as library services are concerned.

The Council of the Library Association in its statement follows closely the conclusions of the McColvin report. There are, in its view, four paramount conditions for the development of sound library service throughout Britain. First, the provision of adequate services by suitable library authorities must be made compulsory. Secondly, there must be an appropriate department of the central government responsible for guiding, encouraging and co-ordinating the work of local library authorities and insisting upon their efficiency. Thirdly, all local authorities must be made financially able to attain efficiency; and fourthly, the composition and size of local government areas must be such that the best results are made possible.

In regard to the essential requirements of any system of library service, the statement makes five points. An adequate service must be available to everyone, irrespective of where he may reside, and must include not only reasonable access to appro-

* The Public Library Service : its Post-War Reorganization and Development. Proposals by the Council of the Library Association. Pp. 16. (London: Library Association, 1943.) 6d. 
priate service points, but also the right and the opportunity to draw upon whatever wide resources of books and professional services each individual may require. Every accredited person should be enabled freely to borrow books from, or consult books in, any public library, regardless of his place of residence or employment. The library service should be so organized and provided that it can meet all the legitimate requirements of the community for books and information. Libraries must be controlled by library committees of men and women chosen for their interest in the service and their appreciation of its possibilities, and responsible directly to their local authorities. Finally, libraries must be staffed by capable and experienced chief officers with sufficient suitable and qualified assistants.

The Library Association holds, and we think rightly, that the public library is essentially a local service, and one that should be intimately related with, and responsive to, local needs. Nevertheless, it considers that each library authority's area must embrace a socially cohesive unit, a normal natural congregation of people, and be well related to their ways of living, interests and occupations. In general, the population of a library area should be between one quarter and three quarters of a million, and the area will embrace not only the nucleus large town but also all the surrounding area which is closely related culturally and commercially. This, it is recognized, involves reform of local government areas and functions.

Failing the creation of a new Ministry or Government Department concerned with libraries, museums and other cultural matters, the statement urges that the Board of Education should be made responsible for guiding, co-ordinating and encouraging the development of local library services, but that this responsibility should be exercised through a new and distinct library department of the Board. The officers of this department should be appointed specifically for, and engaged solely upon, library matters. Grants to library authorities from the national exchequer will be necessary to make possible the provision of adequate library services throughout the country, but such grants must be made contingent upon the maintenance of sufficient suitable service points, satisfactory expenditure on books, the employment of sufficient and appropriately qualified staff and payment of agreed national scales of salaries for all grades.

According to the McColvin Report, reference library work is the outstanding failure of librarianship in Great Britain. The Association's statement proposes that a limited number of existing large reference libraries should be specially developed as regional reference libraries. All local authorities should maintain suitable special collections which would form centres for information and bibliegraphy in their respective special spheres for the benefit of the whole country. The National Central Library should be strengthened and developed, and fully supported by adequate grants from national funds, to provide an efficient system for the interchange of the more specialized, older and less readily obtainable material.
Both local provision and more comprehensive bookstocks should reduce other inter-library lending to a minimum, but the National Central Library should maintain the appropriate union catalogues, develop and maintain co-operation between libraries of all kinds, encourage and co-ordinate the development of special libraries, act as a national centre for biblio. graphical information, organize international loans, and act as a centre and clearing-house for biblio. graphical information regarding the literature of foreign countries. The cataloguing of books and the provision of necessary bibliographical assistance for readers and library staffs should be undertaken on a national basis by a central cataloguing department which could appropriately be part of, or closely associated with, the National Central Library.

Passing over the detailed discussion of the question of qualified staff, the general argument of which should be assured of the support, of scientific workers, we note that an adequate and efficient public library service is regarded by the Library Association as a necessary background to any scheme of adult education. The public library is not to be regarded primarily as a part of the formal educational machinery, and its place in the community is well indicated in this section of the statement. Welcome emphasis is laid on the importance of relating the public library service as closely as possible to all other types of libraries, such as those of universities, government departments, scientific and research institutions, etc., and the national libraries. It may well be hoped that the attention now being given to rehabilitation and reconstruction of libraries all over Europe may lead to more attention being given to the fundamental problems of library co-operation and relations be. tween special and general collections. The War has clearly stimulated closer co-operation, but it should be remembered that inter-library loans are expensive and intrinsically inefficient. Our object should be to create the conditions in which such loans are reduced to the minimum.

There can be no doubt that the Library Association is right in its affirmation that post-war Britain will need and demand a better library service than has yet been fully envisaged by local or national authorities. It will be remembered that in "Redbrick University", Bruce Truscot stresses the importana of the university library in stimulating thought in undergraduates. Development and expansion of the university libraries to meet the post-war situation can scarcely be entirely without reference to the reorgani zation and development of the reference library system, or to the special libraries, if only because of the difficulties and problems in the distribution and replacement of stocks, particularly of scientific and technical periodicals and the like, to which some reference was made at the recent conference held by the Association of Special Libraries and Information Bureaux. The Library Association thus covers ground of the closest interest to scientific workers, and their support as citizens should be assured for the thorough revision of the law relating to public libraries required to implement the proposals of the Association. 